\title{
Female Principals' Narratives of Leading Schools in the Time of the COVID-19 Pandemic
}

\author{
Felicia Williams \\ ORCID iD: https://orcid.org/0000-0002-9870-9565
}

\section{Juliet Perumal \\ ORCID iD: https://orcid.org/0000-0002-4060-9510}

\begin{abstract}
Educational institutions worldwide have weathered several challenges and crises, ranging from school curriculum changes, school closures due to political turmoil, outbreaks of disease, and natural disasters. The last two decades have seen the rise of natural disasters and global health crises and currently, the coronavirus disease 2019 (COVID-19). South African education has not been immune to these challenges and crises. The outbreak of COVID-19 has resulted in global disruption to education institutions marked by the prolonged closure of schools and school community members falling ill and succumbing to the disease. The outbreak and its impact have necessitated school leaders successfully navigating their staff and students through an unprecedented dispensation.

Drawing on critical feminist theoretical insights about leadership ethics and women, inter- and trans-corporeality, and emotional and affective labour, this qualitative study reports on four female principals' leadership experiences at independent and public high schools in South Africa. Data about the leadership experiences of the participants were generated using various e-platforms. The study explored the personal and professional challenges the female principals experienced during the COVID-19 crisis in relation to contextual factors such as the geographical location of the school; socio-economic status of parents and their involvement in remote teaching and learning; the availability of resources, and their leadership styles, philosophies, and responses to the pandemic, prior to, during and after the national lockdowns.
\end{abstract}


The study revealed that despite experiencing anxiety over the uncertainty of life in general, their perseverance, resilience, ethic of care and empathy and fostering collaboration amongst staff and parents contributed to successfully navigating their schools through the early stages of the COVID19 pandemic. The pandemic also amplified the socio-economic disparities between independent, resource-rich schools and disadvantaged government schools and its subsequent impact on these schools transitioning from traditional to online teaching and learning.

Keywords: COVID-19, women in education leadership, feminist theory, phenomenology, crises leadership, South Africa

\section{Introduction}

In December 2019, there was a rise in the reported number of pneumonia cases in Wuhan City, China (South African Department of Health 2020). On 7th January 2020, the World Health Organisation (WHO) identified severe acute respiratory syndrome coronavirus 2 (SARS-CoV-2) as the cause of the rise in illnesses in Wuhan, China (United Nations Educational, Scientific and Cultural Organisation (UNESCO) 2020). The infection caused by the novel coronavirus has subsequently been called the coronavirus disease 2019 (COVID-19). The virus is transmitted from person-to-person through respiratory droplets, emitted when an infected person coughs or sneezes (WH as cited in UNESCO 2020). Subsequent to the discovery of this virus, it spread globally, including to South Africa (South African Department of Health 2020). On 11th March 2020, the WHO declared a global pandemic and crisis (Mahaye 2020).

In response to this global crisis, on 15th March 2020, the South African President, Cyril Ramaphosa, invoked the Disaster Management Act of 2002 as amended in terms of Section 27(2) of 2020 and declared a National State of Disaster. On 26th March 2020, South Africa was placed under a national lockdown with severe travel and movement restrictions imposed throughout the country. The state of disaster announcement resulted in the indefinite closure of all South African schools (News24 2020) and plunged the 2020 academic year into disarray. School principals were thus tasked with successfully navigating their staff and students through this state of uncertainty. 
While COVID-19 is described as being caused by novel virus, Stern et al. (2009) note that plagues, pandemics, and epidemics are not new phenomena. There have been a number documented globally over many centuries. In providing a historical overview of education during plagues and pandemics - such as the bubonic plague in the 14th century and the Spanish influenza in 1918. In writing about the Spanish influenza of 1918, Atterberry (2020) reports that the city of Los Angeles in the United States of America (USA) substituted in-person teaching with mail-in (correspondence) modules for high school students to complete at home. Furthermore, Atterberry (2020) recalls that educational institutions had to swiftly institute mitigation strategies to contain the spread of diseases, preventing infection of staff and students. According to Carlton (2020) in the absence of modern-day pharmaceuticals such as vaccines and antivirals or testing and tracing measures, educational institutions of the past also implemented protective nonpharmaceutical measures. Morse (2007: 7313) writes:

A variety of interventions were available in 1918, from wearing surgical masks to 'social distancing' measures (as we call them today) that ranged from closing schools and prohibiting public gatherings to isolating sick people in hospitals or encouraging them to stay [at] home. Most of the interventions then available are identical to the measures that would be considered today.

Evidently, principals are routinely tasked with navigating their schools through various challenges and crises. The last two decades have seen the rise of natural disasters such as Hurricane Katrina (2005), Cyclone Nargis (2008), and Tangshan Haiti Earthquake (2010); and global health crises such as the Human Immunodeficiency Virus (1980 - the present), SARS (2002 2003), swine influenza (2009), Ebola (2014 - 2016), Zika virus (2015 2016) and currently, the coronavirus disease 2019 (COVID-19). Reminiscent of the various crises that have impacted education globally, such as fluctuating socio-economic climates, changing school demographics, fiscal constraints, dwindling educational resources, parental involvement and political instability - COVID-19 has yet again foregrounded the increasing demands and changing roles and responsibilities that beset school principals (Bush \& Glover 2016). The COVID-19 pandemic has impacted the educa- 
tion, socio-economic, psychological, and emotional ecologies of both individuals and societies (Miller 2020).

In writing about school crises management - specifically in the USA, Gainey (2010), Boin et al. (2013) and Drake (2018) note that there is a mounting focus on historical crises such as the $11^{\text {th }}$ September 2001 terrorist attacks, school shootings and recurring natural disasters. Powers and Azzi-Huck (2016) have written about the impact of Ebola on education in Sierra Leone during the eight-month school closures - this on the heels of several years of civil unrest. Obura (2003) has written about crisis management and school reconstruction in Rwanda post the genocide, and de Klerk and de Klerk (2020) have written about crises containment management in South African schools. These scholars have explored these crises events to learn lessons about effective crises management and directions for future actions (McCarthy 2012; Moore 2018). Notwithstanding the mounting corpus of literature on the best leadership approaches for crises management, there is a silence/absence of information about these leaders' actual lived experiences.

Although teaching/education is a highly feminised profession, patriarchal sensibilities pervade and define education leadership and management scholarship (Moyo \& Perumal 2019). Feminist scholars continue to agitate for redistributing the narrative field so that the voices and experiences of women education leaders can be relocated from the periphery of social theatre. Furthermore, the reports on women political leaders successfully navigating their countries during the COVID-19 pandemic reveal the importance of effective leadership during a time of crisis. In this regard, Wittenberg-Cox (2020: 1) asked:

Looking for examples of true leadership in a crisis? From Iceland to Taiwan and from Germany to New Zealand, women are stepping up to show the world how to manage a messy patch for our human family. Add in Finland, Iceland and Denmark, and this pandemic is revealing that women have what it takes when the heat rises in our Houses of State. Many will say these are small countries or islands, or other exceptions. However, Germany is large, and the U.K. is an island with very different outcomes. These leaders are gifting us an attractive alternative way of wielding power. What are they teaching us? 
It is against this background that this study explored the lived experiences of four South African female principals who have been leading their schools during the COVID-19 pandemic.

\section{Theoretical Insights}

\section{Dismantling Dichotomous Thinking in Education Leadership}

Public discourse and everyday social practices around gender have perennially been dominated by a binary logic that creates a hierarchy between man/ woman, mind/body, culture/nature, reason/emotion, public/private, and objective/subjective. This discriminatory logic has perpetuated hierarchical gender differences and dualisms to the extent that men are still associated with the mind, culture, reason, ethics, the public realm and objective knowledge. In contrast, women are associated with the body, nature, emotion, the private realm and subjective opinion. Resisting this reductionist and artificial dichotomy, women want their different perspectives, capacities, work patterns and viewpoints integrated into how things are understood and executed, known and valued. With education institutions being notorious for replicating patriarchal family configurations (where school headship is assigned to males and followership and nurturance are expected of women educators), feminist scholars such as Blackmore (2013), Naidoo and Perumal (2014), Zikhali and Perumal (2015) have documented the call for a radical transformation in the discourse on education leadership and management.

Pullen and Vachhani (2020) are critical of how women's leadership has been understood in relation to male leadership, rather than on its own terms. They are particularly critical of how women have been typecast as different from men and as deficient. They argue that the default, normalised association and understanding of rationality with masculinity and leadership when framed in opposition to feminine emotionality, respect, care, and concern is limiting and prejudicial. They further contend that when women in leadership are expected to become honorary men, the resulting anxieties, psychic disequilibrium, and dissonance women experience situate women in the contradictory position of being masculine and feminine simultaneously. Essentially, women are required to perform the masculine, rational, omnipotent, heroic order of leadership whilst still enacting devalued feminine ideals such as self-sacrifice, emotional attachment, care and empathy. Pullen and Vachhani (2020) contend that education leadership discourses have only 
been able to accommodate one subject - the male subject - thus othering and devalourising the female subject. They thus advocate for:

... a radical vision for leadership that liberates the feminine and women's subjectivities from the masculine order. ... [by offering] a practical project for changing women's working lives through relationality, intercorporeality, collective agency and ethical openness with the desire for fundamental political transformation in how women can lead (Pullen \& Vachhani 2020: 1).

In discourses on transformative leadership, care and compassion are not viewed through a gendered lens, thus these values are not seen as opposetional to being firm, assertive, decisive, authoritative. Transformative leadership instead illustrates how women enact alternative leadership practices appropriate to the nature of the situation and circumstances. Thus, leadership can be understood in relation to a lived feminism where the individual agency allows the leader to change, challenge and transgressively reshape her personal and professional position instead of mimicking and posturing male leadership.

\section{Feminist Ethics, Intercorporeality and Transcorporeality}

Diprose (2002) conceptualises ethics as being not just about rules, rationality and reasoning, but as a value born out of generosity and openness to the other. Pullen and Rhodes (2010: 246) explain that feminist ethics is characterised by affective encounters with others/otherness made in and through the body. Thus, affective leadership is a relational phenomenon characterised by openness, responsiveness and a radical generosity to difference. It distances itself from a transactional conceptualisation of ethics in which individuals/ or the leader operates as an independent, sole entity motivated by what one can benefit from the interaction/transaction with the other. In contrast, feminist leadership ethics proposes ethics that is intercorporeal, i.e., understanding the self-in-relation to others. It is a relationship premised on an inter-dependence with others that engenders collective agency between/ among leaders and followers. Dahiya (2020: 1-2) reminds us that COVID19 has forced us to rediscover our bodies in relation to fellow human beings and in relation to the environments our bodies interact with (such as public 
transportation surfaces, elevator buttons, office work documents, taxis, cars, buses, aeroplane bathroom door handles, drinking glasses ... who we are physically near to, whom we touch (our loved ones, neighbours in a cramped elevator, fellow public transit passengers, and co-workers). COVID-19 has called attention to relationality as the virus traverses species, populations, and surfaces, cutting across nation-states' boundaries, thus making the local become global and vice versa. Notably, the COVID-19 pandemic has problematised intercorporeality. Human beings do not generally see other human beings as biological threats. Nonpharmaceutical protocols, such as social distancing, self-isolating and quarantining that are required of individuals, discourage human beings/bodies physically interacting/ socialising with each other because individual human beings now pose a biological threat to each other. These strictures have intensified the emotional and affective labour that society, in general, and school principals, in particular, have to engage.

COVID-19 has also reminded us that human beings have a dialectic relationship with the broader material world. Human beings share spaces with other plants and other animal species. Alaimo (2018) refers to this as trans-corporeality. The embodied experience of trans-corporeality in the wake of COVID-19 has forced us to rethink our understanding of the daily, familiar environment and our often-ignored relationships to the broader world. This is especially so given preliminary reports that the COVID-19 pandemic has zoonotic origins, transmitted from animals to humans and then between humans (Salata et al. 2020).

\section{Emotional and Affective Labour}

Hochschild (1983) popularised the notion of emotional labour, which she defined as the management of feelings to create a publicly observable facial and bodily display. Writing specifically about flight attendants, Hochschild (1983: 7) argued that:

$\ldots$ it is the labour of producing affects for the consumer, but one inwhich the worker must induce or suppress [her own] feeling in order to sustain the outward countenance that produces the proper state of mind in others - in this case, the sense of being cared for in a convivial and safe space. Her postures and gestures and her feeling must be managed if she is to create a convincing display. 
In recruiting the concept for an investigation in education, Perumal (2014: 13) contends:

... women educators in particular, [are] tied to the exacting demands of nurturance pedagogies. ... The economic and cultural devaluation of the profession obtains from the emotional labour that educators perform which remains invisible and goes unrecognized and unrewarded.

Blackmore (1996) posits that emotional labour has, traditionally, been couched along gender lines. Hargreaves (2005) points to an emerging body of research on the role of emotions, identity and teachers' work in diverse education contexts. The demand for emotional labour within the education sector has increased exponentially with the advent of the COVID-19 pandemic.

Whitney (2018) notes that more recent scholarship further distinguishes between emotional labour and affective labour. Woodcock (2017) explains that affective labour refers to the mind and body and produces affects which are more complex than emotions. Zembylas (2005) notes the pivot of teachers' work away from an exclusive domain of rationality and predictability towards the role of emotions and affect in their professional practices and experiences.

Kostogriz (2012) highlights the link in teaching, between the rational and the emotional and between the mind and the body. Analyses of the affective labour of teachers (the labour of interaction and social relations) suggest that affect directs teachers' power to enact their practice, and this enactment is governed by feeling, passion and the ethic of care (Ball 2003). This enactment links the power of the mind to think and the body's power to act (Kostogriz 2012).

Furthermore, according to Whitney (2018), scholars of affective and emotional labour posit that the boundaries between work time and leisure time and between work and personal life have been blurred in serviceintensive economies. They argue that an employee's personality and affecttive life have become integrated with the execution of one's job. Emotional and affective labour, which have been the hallmark of women's work (feminised labour - like secretarial and nursing jobs), is becoming inextricably linked to the fabric of work in service industries. 


\section{Flexi-work, Work from Home, Work - Life Balance, and Work - Life Integration}

Dating back to patriarchal family arrangements that scripted the home's private domain as women's natural and rightful place, women's entrance into and participation in the formal economy has embroiled society in debates about the appropriacy, morality, and ethics of women working outside the home. Employed women strive to contribute both as paid workers and as productive family caretakers. Trying to achieve work-life balance is at the heart of the struggle to strike a balance between the demands of employees' family lives and their work lives. Work-life balance refers to the prioritising of 'work' (career and ambition) and of 'lifestyle' (health, pleasure, leisure, family, and spiritual development). Raja and Stein (2014) note that as a concept, work-life balance dates to the manufacturing laws of the $1800 \mathrm{~s}$ when the work hours of women and children were restricted. The concept reemerged in the 1980s when the Women's Liberation Movement agitated for women's inclusion in the workforce with the caveat that their need for flexible work schedules and maternity leave was accommodated to allow women to pursue professional careers and manage their homes and families. Work-life balance and flexi-work have become recurrent themes in the scholarship on gender and work. Literature is replete with women psychoanalysing their feelings - predominantly feelings of guilt for neglecting their children, being too successful in their careers or earning more than their spouses (Bedeian et al. 1988; Naidoo \& Perumal 2014; Allen et al. 2000). Jackson and Fransman (2018: 1) note that expressions such as:

... 'there are not enough hours in the day' and 'the 25-h workday' or cliché statements such as 'working 24/7' have become common overtones in the way employees [express how they] feel about time at work. Because of this 'lack of time' feeling, alternative work arrangements such as flexitime, telecommuting and practices such as work-life balance have emerged as popular topics for researchers, employees, organizations in the past few decades.

Thus, employees have attempted to harmonise their work-life balance by seeking work flexibility, as they try to fulfil work responsibilities and their family roles. Hill et al. (2008: 152) define workplace flexibility as: 
... the ability of workers to make choices influencing when, where, and for how long they engage in work-related tasks. ... it is a multifaceted concept that includes discretion over where work is performed (e.g., telecommuting), the duration of individual and collective sessions of work-related tasks (e.g., part-time employment), as well as options for multiple points of entry and departure from paid work, for example, career flexibility.

Although the concept of a work-life balance was initially directed at women and children, the phenomenon of flexi-work, working from home, and telecommuting has been punted as a win-win situation for both male and female employers and employees. The contention is that flexible working hours - for the most part - enable employees to manage family, personal needs, or organisational needs. The positive slant towards flexi-work has been attributed to increased flexibility, job autonomy, control of work schedules and circadian rhythms (Sukal 2009).

However, the original conceptualisation of work-life balance has given way to the term work-life integration. According to Slaughter (2012), professional working mothers confide that attempting to achieve work-life balance as another measure of success compounds stress and anxiety. This stress potentially contributes to the erosion of their confidence and exacerbates feelings of 'mommy guilt' as they battle the glass ceiling syndrome while concurrently trying to achieve life meaning (Shapiro et al. 2008). The notion of work-life integration is a call to relate to working professional women holistically in their attempts to integrate household demands with career priorities, creating an integrated lifestyle that focuses on the relational and contextual nature of women's careers (Tajlili 2014).

The COVID-19 pandemic has revolutionised workplaces, work hours and work methods due to forced stay-in-place and work-from-home arrangements. However, the link between flexi-work, financial wellbeing, work-life balance, productivity and job satisfaction remains a contested terrain in the South African context because COVID-19 has impacted individuals differently. The pandemic has magnified existing inequalities, e.g., the impact of self-isolating and working from a spacious home with reliable internet connectivity in a job in which one's salary and employment benefits are protected is arguably less taxing than home contextual and relational conditions that are unsafe and unconducive to productivity. 


\section{Research Methodology and Contexts}

This qualitative study was nested within a critical feminist paradigm. It sought to explore the participants' lived experiences through a phenomenological research design. It attempted to understand the psychological and social phenomena of the participants (Hesse-Biber 2010). Purposive sampling was used to identify the participants who met the following criteria: they had to self-identify as South African females, and they had to be principals leading schools during the COVID-19 pandemic. Table 1 captures the biographical details of the participants. Pseudonyms have been used to protect the names of the research sites as well as the participants' identities.

Due to the COVID-19 outbreak and the South African Department of Health's national restrictions, researchers were prohibited from entering schools. Participants were solicited for the study through electronic communication (i.e., e-mail, Zoom and WhatsApp). The four purposively selected participants signed consent forms and their biographic data (age, race, marital status, personal contact details, current leadership position in their school, years of experience in their current position, name, and location of their school and preferred means of communication) was elicited through Google Forms. Zoom Collaborate was used to conduct 60 minute long, individual, semi-structured interviews. Zoom Collaborate is a cloud-based videoconferencing service that creates a platform and offers a variety of online features such as secure online meetings, group chat services and the option of recording the online sessions (Archibald et al. 2019).

Given that the participants were located in different provinces (namely, Gauteng, KwaZulu-Natal and Mpumalanga), conducting the interviews via Zoom facilitated the data generation process as the principals availed themselves at times that were suitable for them. Furthermore, they could participate in research generation activities from the privacy and convenience of their own homes. A WhatsApp Chat Group was also created and remained open for 24 hours. This e-platform encouraged the participants to share, compare, contrast, and elaborate on their lived experiences of leading their schools during the unprecedented COVID-19 pandemic.

Document analysis was used to complement and validate the individual interview responses from participants through drawing on various electronic correspondence between participants, staff and parents. The documents comprised letters, communique detailing COVID-19 protocols 
and procedures, photographs, Facebook and WhatsApp messages of encouragement and motivation sent during the national lockdown and before the reopening of schools.

\section{Table 1: Participants' Biographical Details}

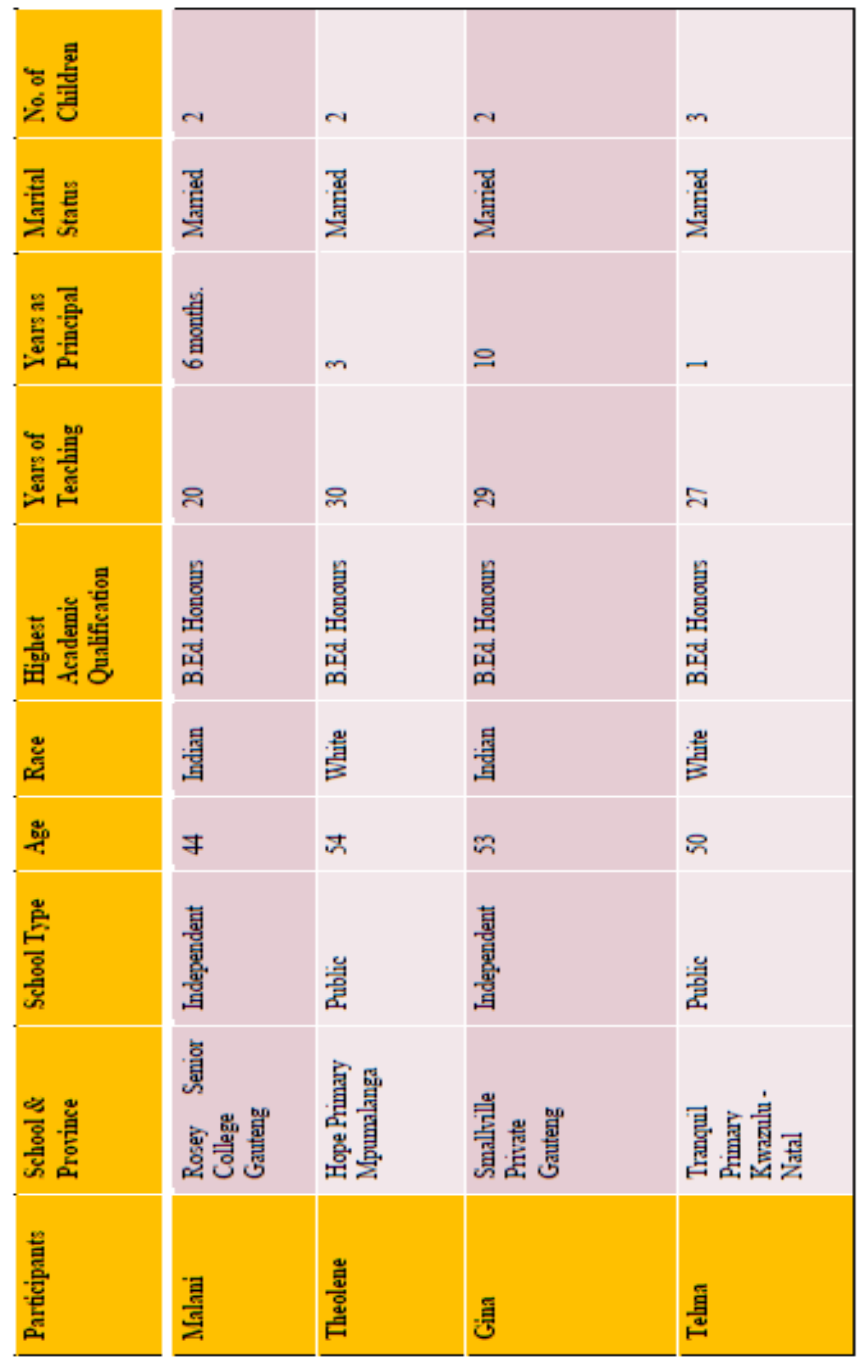


The interview data generated from the audio-visual Zoom recordings were transcribed from voice to text using Transcribe ${ }^{\mathrm{TM}}$, an online software programme. The data were subjected to a two-stage systematic coding process, i.e., open coding, to identify and categorise data by highlighting and labelling important words, phrases, or concepts followed by axial coding (Merriam \& Tidsell 2016) to identify the major themes.

Ethical clearance was acquired from the University of Johannesburg's Faculty of Education Ethics Committee, the KwaZulu-Natal and Mpumalanga Provincial Departments of Education, and the respective School Governing Bodies (SGBs). Letters requesting permission to conduct research in the independent schools were sent to their respective Board of Directors. Additionally, letters of invitation and informed consent forms were e-mailed to each participant. The invitation letter explained the aims, objectives, procedures, benefits and potential risks of the study and the researchers' commitment to anonymity and confidentiality. The study involved participants sharing their personal and professional experiences of leading during an emotionally, spiritually, and physically volatile and traumatic period. The participants were made aware of the professional government counselling services that had been especially established for educators, if they felt the need to make use of this service.

Rosey Senior College is located in a suburb in the East Rand of the Gauteng Province. It has a school population of 1050 learners. The school campus is situated in an affluent area with spacious, free-standing estate houses and gated complexes, shopping malls and a golf course. A large section of the community comprises upper-class white business owners and professionals. The majority of the school learners and staff reside in and around this area. The school boasts state-of-the-art academic and sports facilities.

Hope Primary is an ex-Model C school (i.e., a privileged school established by the South African apartheid government for white students). It is situated in a predominantly agricultural town, close to the Vaal River in the Mpumalanga Province. The school caters for 678 learners, a sizable portion of which is made up of Black learners, who hail from the surrounding disadvantaged communities. The neighbouring townships comprise shacks and low-cost RDP dwellings (which is a government-funded social housing project built as part of the African National Congress' Reconstruction and Development Plan). Learners travel to school by buses, taxis and/ or on foot. 
Smallville Combined Christian School is an independent school situated in northern Johannesburg, Gauteng Province. The school hosts approximately 100 learners and is located in a quiet suburb with leafy green tree-lined streets, gated complexes and townhouses. The suburb is close to trendy shopping malls and other prestigious schools and is home to predominantly middle to upper-class Black, Indian and white residents. Most parents are professionals who are employed full-time in and around Johannesburg.

Tranquil Primary school is located on the border of KwaZulu-Natal Province and the Eastern Cape Province. The school caters for approximately 328 learners from the surrounding areas. However, many learners travel 40 kilometres across the borders from the Eastern Cape to attend the school. Most residents in the school community earn an income through the local tourism industry. The population is predominantly white English-speaking residents who are alma maters of the school. Given that hills and valleys surround the school, it often experiences poor WIFI connectivity.

\section{Discussion}

\subsection{Leading through Uncertainty in Unprecedented Times}

A crisis is defined as a specific unexpected or unprecedented situation or string of events that creates high levels of uncertainty and poses an imminent or severe threat to life, property, or to an organisation (Klann 2003; Nyenswah et al. 2016). Kezar and Holcombe (2017) postulate that mismanaging a crisis can damage a school's reputation and diminish followers' trust in the school principal. The principals that participated in this study experienced an array of emotions when South African President Cyril Ramaphosa declared a national lockdown and the closure of all schools for an indeterminate period. All the participating principals conceded that the announcement of the national lockdown and spread of COVID-19 made them feel fearful and sparked high levels of anxiety and uncertainty in them and among their staff, learners, and the school community.

Malani, the principal of Rosey Senior College, recalled that the announcement of the national lockdown and early termination of the school term caused her great anxiety. She was unsure as to how she was going to navigate the school through this uncertainty. To mitigate her sense of uncertainty, she decided to research options for her school ahead of time, 
working until midnight the evening before the national lockdown and throughout the holidays - instead of awaiting advice from the Independent Schools Association of Southern Africa (ISASA). In the WhatsApp chat component of the study, Malani mentioned that being a principal of an independent school, she was able to exercise her prerogative to decide whether to continue with schooling during the national lockdown or not. By virtue of this autonomy, she was at liberty to make changes to the academic school calendar and resume schooling online on 14th April 2020. Malani's actions support Mayer et al.'s (2017) findings which reveal that women are more resilient and adaptable when handling psychological setbacks in times of crisis and instability.

Gina, who is also the principal of Smallville Private School, had been visiting her daughter in Dubai when the national lockdown was announced. Given the closure of international borders and the suspension of international travel, she was effectively locked out of South Africa. Gina reminisced:

I was a bit nervous. Being physically in Dubai was difficult for me, but I had to tell myself that 'I've got to work with what is available in terms of technology.' I had to make it for my staff and myself because I realised that this is how it's going to be. We're going to use the technology now; we're not going to worry about not having $\mathrm{X}, \mathrm{Y} \& \mathrm{Z}$.

We are a small school. We pretty much ran our show, using all the guidelines. We did not receive any support from the Gauteng Department of Education at the onset of the COVID-19 pandemic and school closures.

In collaboration with the school board and staff members, Gina led her school through the migration from contact teaching and learning to remote online teaching and learning during the first month of the national lockdown in South Africa.

On account of the technological resource affordances and accessibility, she could also conduct online meetings with her staff and parents to keep them abreast of decisions about the 'new normal'. Gina's response to the national lockdown and the education crisis reflects the 
resilience of female leaders. Youssef and Luthans (as cited in Eliadis 2019: 199) contend that positivity and optimism are crucial and effective leadership traits in challenging times. Followers experience greater reassurance and respond better to the 'happier-and-smarter' rather than the 'sadder-but-wiser' leadership approaches. Gina, like Malani, also had the autonomy and freedom to modify her school's academic calendar to decide when her school would recommence teaching and learning.

Theolene, who is the principal of Hope Primary School, described her thoughts and emotions about the lockdown as follows:

I felt scared. I was terrified because we saw the videos posted on Facebook and all the messages on social media. We did not know what was coming and what is happening, and will you get this COVID-19, or will you be, okay?... There was little communication between the circuit manager to [and] principals because we could not communicate. Most of us were not familiar with the online meeting platforms such as Zoom and Teams at the time and not all staff had access to WIFI. Furthermore, the circuit managers were also awaiting instructions from the DoE.

Principal Theolene was unable to address the uncertainties and calm the anxieties of staff and parents because she needed to wait to receive directives from her superiors, her Institutional Development and Support Official (IDSO) and the circuit manager. Smith and Riley (2012) posit that crisis mitigation and effective crisis leadership are contingent on clear, concise, relevant and timely information shared with stakeholders. Effective crisis leadership can be achieved by ensuring open communication channels, cultivating environments with better direction, certainty, and optimism. In the face of mounting anxiety and uncertainty among staff and parents, Theolene had to navigate the hierarchical and bureaucratic Department of Education (DoE) structures. Her inability to exercise discretionary autonomy testifies to the debilitating power imbalances inherent in the system. It confirms the contention that women's decision-making powers are often inhibited by the chain of command that present themselves through, for example, district and circuit managers (Oyeniran \& Anchomese 2018). These hierarchical structures in the DoE may be reflective of the patriarchal influences that inform organisational structures. 
Telma, the principal of Tranquil Primary, a public school in KwaZulu-Natal recalls:

I initially thought, how in heaven's name are we going to do this? To think that you're trying to run a school and keep everything going and be open to having a positive mindset? I also felt stressed because how are the parents going to cope with this? How are the children going to cope with this? You didn't have a plan, or we were stressed because of the academic year - or just wow! - Just everything.

The string of questions in Telma's excerpt illustrates her sense of feeling lost, confused and overwhelmed. The impact of this unprecedented crisis was beyond anything she or the school community could have planned for. She expressed uncertainty about managing the logistics and the emotional wellbeing of her school community.

In their responses, each principal experienced varying degrees of emotional turmoil and uncertainty in the face of the COVID-19 crisis. A significant amount of emphasis was placed on the loss of direction they experienced. These circumstances were especially so for Telma and Theolene, principals at public schools. They had to rely on stringent directives from superiors in their respective district offices. Their need to wait for permission to act exacerbated their uncertainty and anxiety.

Malani and Gina, on the other hand, also experienced initial feelings of panic and uncertainty. However, due to resource availability and more leadership independence and flexibility, they could migrate to online teaching and learning, resulting in their schools resuming teaching and learning sooner than those of Telma and Theolene. The autonomy exercised by Malani and Gina as principals of independent schools, reflects the socioeconomic inequalities that characterise South African society. Dube (2020) contends that the COVID-19 strategic plans for South African schooling have once again exposed how the marginalised and socio-economically disadvantaged lack the agency and opportunities enjoyed by those who enjoy economic privilege.

\subsection{Leadership Approaches Adopted during COVID-19}

Three out of the four principals indicated that their leadership styles are de- 
pendent on the situations at hand, i.e., they exercise contingency leadership. Participants, Theolene and Malani mentioned that even though they prefer collaborative decision-making and distributive leadership, they are guided by the nature of the prevailing situations. When a decision must be taken immediately and if they are ultimately accountable for those decisions, they make unilateral decisions.

Malani reflected on the episode when due to the COVID-19 regulations, she was forced to cancel the grade 12's farewell event despite her staff being divided on the issue. Given that she would ultimately be accountable for the learners' safety, she decided to cancel the event. As a new principal who had been at the school for just six months, she confided:

There is no one style of leading or managing. ... It all depends on the situation. Certain decisions have to be taken autocratically and in other instances, I am able to consult with my staff. The issue is how soon a decision needs to be made as well as who is accountable for the decision [which is] to be made. ....

I am the only non-white person at the school, and it is very difficult for people in some instances to take direction from someone who is not white, a.k.a [also known as] myself.

Malani came across as a very stern leader but made it clear that her ultimate purpose is to work alongside her staff. She continued:

I don't believe in barking out orders, I like to do things with them [colleagues]. Setting the example so that they can see that I am invested and don't consider myself to be superior to them.

I needed to make quick, decisive decisions. However, these decisions were always in the [best] interest[s] of the parents, children, staff and school as a whole.

Malani's decision was rendered all the more contentious when viewed within the race and gender power matrix. Malani volunteered the following episode of resistance when it came to her leadership at Rosey Senior College. A South African principal of Indian descent, Malani reiterated that she is the only Black person amongst her staff. As a result of the school and staff's 


\section{Felicia Williams \& Juliet Perumal}

historical and current racial demographics, both parents and staff have a particular view of how the school should be run. Malani described herself as a 'no-nonsense' type of person who leads by the book. When she arrived at the school six months prior, she followed up on how the various school policies were being implemented. This implementation of the policy review was much to the consternation of the majority of her staff. She described these acts of following-up as her way of 'cleaning house' in a school where the previous principal refused to act against staff misconduct. Malani mentioned that the staff had labelled her as 'vindictive' and 'mean'.

She also recalled a female teacher's insubordination incident during the phasing out of national lockdown and the July examinations. The teacher refused to mark a learner's online examination because she deemed it as a late submission. After lengthy correspondence with the learner's parent, Malani addressed the issue and instructed the teacher to contact the parent and to mark the learner's examination submission. The student had comorbidities and had also experienced technical problems while trying to submit his examination online. The teacher categorically refused to mark the examination submission. She retorted: 'I don't have to listen to you or the [learner's] parent'. She mentioned that this is but one example of the continuous pattern of most of the staff's subversion of her authority.

Such microaggressions perpetuate the oppression of Black women in leadership. Malani admits that as a non-white woman leading in a predominantly white upper-class context, she receives little support.

Gatwiri (2021: 1) defines microaggression as:

... brief and commonplace daily verbal, behavioural and environmental indignities, whether intentional or unintentional, that communicate hostile, derogatory, or negative racial slights $[\ldots]$ put downs, or a pattern of disrespect.

Racial microaggressions in the workplace generally take covert or subtle forms and may be conceptualized as 'everyday' or 'passive' racism that serve to invalidate or inferiorise the expertise of Black people while positioning white expertise as the standard of 'best practice'.

Malani's experience lends credence to the contention that gender discrimina- 
tion within rigid hierarchical structures can be covert, subtle and nuanced, or can manifest through blatant and harsh microaggressions, microinsults and microinvalidation of women's positional authority.

The palpable racial and gender biases that Malani experiences at her school have compelled her to adopt an autocratic leadership style. Malani arguably adopts this approach to combat the microaggressions to which she is subjected. The following interview excerpt reveals her internal soliloquy, which she has formulated as a 'parodic imitation', a defence-mechanism against the oppressive opinions of parents and staff:

If you [parents and staff] have an issue with me not being white, that's your [parents' and staffs'] problem. If you [parents and staff] are not happy, go and find an all-white school. This is the new South Africa.

Malani resorting to blunt and bitter speech, expresses a culturally silenced truth about the implicit bias and racial tensions. By explicitly ventilating her truth, she recuperates her sense of feeling unworthy as a result of her race and gender and exemplifies a practice of self-transformation by parading her leadership capabilities to gain the confidence of her exclusively white school community.

Malani conceded that her initiatives and resilience as a leader during the COVID-19 school crisis precipitated a change in the staff's responses to her. She reported:

I think the staff gained more confidence in me and they didn't think, you know, she's a stupid non-white woman - like 'who the hell does she think she is?' So yes, it basically reassured them that I could do the job. I am the right person to take action. It certainly made the school board realise I was the right person for the job because I received a significant salary increase.

Malani is conscious of the intersectionality at play in her work environment and how they influence her power enactment.

Theolene mentioned that some of her staff refer to her as 'Moses' because she took the lead just like Moses did in biblical times - leading the Israelites towards the promised land. Theolene said: 
I do not give the instructions to staff and expect them to implement it [them]. I met with them in the mornings. I also go [went] to the duty point checking and [was] making sure that everything runs smoothly. The teachers noticed that I am not just looking from the outside, but I'm also part of the work team.

Bartling (2013) argues that women's leadership is more people-orientated and often characterised by collaborative decision-making. This is in stark contrast to men's leadership, characterised as assertive, objective and selfreliant.

All the participating principals in this study indicated that although their leadership roles and responsibilities required them to exercise various leadership styles, their leadership philosophy leans towards a preference for post-heroic, collaborative leadership, leading by example and the empowerment of their staff. Their leadership philosophy is consistent with accounts of feminist leadership, which foster non-hierarchical, horizontal working relations (Moyo \& Perumal 2019). This variant of leadership conceives leading and following as two sides of the same coin. The relational skills that are generated from this kind of leadership foster interdependence.

Standing in stark contrast to heroic leadership styles that focus on producing effective outcomes, post-heroic leadership measures success by how people grow. In reviewing the leadership approaches that the participants in this study adopted during the national lockdown of schools, we see that when the need arose to be assertive, aggressive, and to display authority, the participants did not shy away from this, despite stereotypical expectations of females to be submissive and compliant.

\subsection{Intercorporeality: Staff and Parents Co-operating and Collaborating}

The interview and document data provide overwhelming evidence that the participants demonstrated great empathy and consideration in their communication with their staff during the national lockdown. At Tranquil Independent school, Principal Telma indicated that she regularly checked on her staff and sent them well wishes on their WhatsApp group. She succeeded in cultivating a caring culture which her staff emulated. Upon returning to school after the national lockdown, she noticed that her staff appeared more 
appreciative of each other, were more willing to assist one another and had forged closer bonds of collegiality. She offered the following example to illustrate the point:

When certain grade teachers were teaching, the other teachers were willing to say, 'No hang on. They don't have to do duties. We will step in to do duties around the school.' Staff were stepping up [to assist] a lot quicker than they had previously.

Gina, the principal at Smallville, would regularly include her staff in e-mail messages she sent to the school board. She consulted her staff and requested their feedback/input when making school-related decisions. Phrases such as 'Please may I have your input/suggestions ASAP' and 'Please check and let me know if we need to adjust anything' would often appear in Gina's correspondence to staff. In the interview, Gina stated: 'we agreed, we shared, we talked about ... '. Pronouns such as 'we' and 'your' reflect democratic school leadership, where a collaborative school culture is nurtured and maintained. Gina cultivated a culture of collaboration amongst her staff. Creating collaborative cultures is consistent with Bond et al.'s (2000) depiction of feminist leadership that attempts to provide a platform for the previously marginalised and voiceless by creating a collaborative and inclusive environment in which 'all members are heard and engage in growth and development with reciprocity and mutuality' (Bond et al. 2000: 699).

Furthermore, Hougaard and Carter (2018) posit that leaders could face and withstand crises by building more mindfulness, collaboration, and empathy in their organisations so that trust and social cohesion are in place when a crisis becomes more challenging. Autocratic and hierarchical leadership responses to a crisis pose the risk of creating division instead of unity.

Parents' active involvement in and support of their children's schooling are regarded as essential to enhancing learner academic achievement (Segoei \& Bisschoff 2019). All four principals confirmed that most parents made concerted efforts to engage with teachers during the national lockdown and the transition to remote teaching and learning. Parents communicated with teachers to clarify what work their children had to complete and/ or to express thanks to teachers for their pedagogic and affective labour. The principals reported an increase in parent involvement and support during this time. The principals surmised that parents realised the enormous addi- 


\section{Felicia Williams \& Juliet Perumal}

tional administrative, pedagogic and emotional demands teachers had to bear. Generally, parents were more forthcoming when their assistance was requested - to the extent that there was suspicion that some parents were doing their children's schoolwork for them. Parents' increased support could be attributed to the possibility that during the national lockdown, most parents were at home and had more time to engage with their children. Working parents are often too preoccupied with their work responsibilities and may not fully engage in their children's schooling under normal conditions. At Smallville independent school, Gina admitted that although parents experienced certain frustration levels with their children's online learning, they appeared to have become conscientised and empathetic towards teachers' experiences in the classroom. At Rosey Senior College, Malani noticed that the complaints from parents were significantly reduced. Interview responses from principals showed a positive rapport between the staff. However, Jaegar and Blaabaek (2020) caution that this may not represent all South African schools. Data from pre-pandemic studies (Kainuwa \& Yusuf 2013; Cheng 2018) reveal that parents from privileged socio-economic backgrounds provide more academic support to their children. The data from this study do not, however, reflect how the stress of job losses, reduced work hours, and changes in the economic status of parents influenced their responsiveness to their children's academic needs.

\subsection{School Leadership, Socio-economic Disparities and COVID-19}

Schools are a microcosm of the broader macro society, where parents, community members, businesses, and various stakeholders have vested interests in their existence. Principals in general and women principals in particular, are affected by the cultural impulses prevalent in the social context of the school. The four participating principals revealed that the school-community's socio-economic status primarily influenced their leadership trials and triumphs. A growing body of studies (Black et al. 2020; Jansen 2020; and Netolicky 2020) draw attention to the unequal distribution of the novel coronavirus, which has rendered vulnerable populations more susceptible to infection and has reconfigured socio-ecological relationships in equations that reproduce inequalities and privileges.

In this regard, Bullard (2020: 165) writes: 
... not all communities are created equal. COVID-19 is not the biological equaliser reducing our socio-ecological structure to the bare strength of our bodies. Race, class, gender and history matter in this pandemic. Many countries impoverished by colonial and neoliberal extractivism and exploitation have extremely weak health infrastructures; epidemics do not occur in a void, acting instead in combination with lack of food, inefficient sanitisation and poverty.

From the four principals' narratives, it is clear that none of their schools is situated in a significantly disadvantaged area. Principal Malani of Rosey Senior College remarked:

We are located in a very affluent area with professional parents, business people and so forth. When they say 'Jump!', I must ask: 'How high?'

We are really very blessed. We were able to procure foot pedal sanitiser stations, add more taps for the kids [learners] to wash their hands, in addition to acquiring the usual Personal Protective Equipment (PPE). It cost the school a hell of a lot [significant amount] of money, but we were fortunate to purchase these necessities.

Malani mentioned that the parents' and teachers' affluent socio-economic status rendered the migration from contact teaching to online teaching and learning reasonably effortless. This community's technological affordances meant that the students already had Gmail accounts and iPads and most staff members already had high-speed internet and relatively stable WIFI connectivity in their homes. Their technological affordances facilitated online teaching and learning. Cheng (2018) and Owusu-Fordjour et al. (2020) observe that resource-rich schools and teachers can better optimise teaching and learning. Lee and Hallinger (2012) argue that an immediate community's socio-economic status significantly influences how school principals lead and allocate their time for their leadership responsibilities.

Principal Gina at Smallville School explained that the parents of the enrolled learners are not wealthy. They are predominantly working-class, single mothers who want the best for their children. Despite parents earning 
good salaries, she noticed that since April 2020 (following the national lockdown) and school closures had resulted in almost $40 \%$ of parents absconding from paying school fees. The financial losses resulted in her implementing a $15 \%$ salary reduction for all teachers. Furthermore, two teacher assistants were retrenched. Due to parents' and staff's financial constraints, various concessions and arrangements were made to alleviate parents' and staff's financial burdens. For example, when the school migrated to online teaching and learning from home, the school supplied staff members with data bundles.

Despite Hope Primary being situated in a town, most learners travel to school from the surrounding disadvantaged townships. Theolene mentioned that certain decisions that she made post the national lockdown were informed by the fact that:

... some parents have lost their jobs and others got a decrease in salary or a salary cut. I sent a letter to parents at the beginning of the lockdown reminding them that even though their children are not at school they are supposed to pay the school fees. The reaction from some of the parents was, 'We cannot pay school fees because we do not have jobs. We lost our jobs'.

Theolene mentioned that local business sponsorships enabled the school to procure the necessary PPE needed as per COVID-19 school regulations. She recalled:

The Department of Education said that we must disinfect and fumigate our schools. A local business decided they will assist the town schools for free. They also donated dispensers for sanitiser, information posters and a temperature reading device [thermometer].

The excerpt suggests that Hope Primary School's significant social capital reconfirms the importance of school community involvement and support especially during a crisis. However, what is striking is the qualification '... they will assist the town schools'. This phrase highlights the systemic biases which widen the financial disparities between the 'haves' (town schools) and the 'have nots' (township schools).

The decline in parents' socio-economic status and the lack of access 
to technological resources inhibited the school from engaging in online teaching and learning. Dube (2020) observes that the migration from traditional teaching and learning to online learning resulted in many learners in rural and urban areas being locked out and excluded from schooling because of limited or no access to resources such as internet connectivity, digital devices and electricity, along with exorbitant data costs.

As small business owners operating in the tourism industry in Durban's coastal city, many parents of learners from Tranquil Primary were adversely affected by the national lockdown. Principal Telma confided:

Many of our parents don't have access to e-learning, and it didn't seem right to establish a communication platform that would benefit a few while the majority would not be able to access it.

Given the unavailability of technological resources and considering the dire economic circumstances and inadequate resources of the parents and learners, Tranquil Primary resorted to making photocopies of the learners' weekly work activities. Parents then had to collect the photocopied material from the school every week. Telma mentioned that the extensive printing and photocopying of learning material incurred additional financial costs in an already exhausted school budget.

Telma's act of factoring the socio-economic status of her school community into her decision-making aligns with critical feminist perspectives that posit that leadership decisions have to be made with cognisance of the broader cultural, social and economic context in which an organisation is located (Perumal 2015).

It is evident from the principals' responses that the COVID-19 crisis has made the social divides between independent schools such as Rosey Senior College and public schools such as Tranquil Primary and Hope Primary schools more pronounced. Such inequities affirm the views expressed by Netolicky (2020) that COVID-19 has resulted in an education crisis that is shining a spotlight on the adverse inequalities that plague education systems worldwide. She argues that the reality of the COVID-19 crisis has brought equity into sharper focus as schools, universities and policymakers are left to interrogate learner access to digital devices, internet connectivity and community support. The digital divide experienced in this time of crisis reflects the various other social and economic divides in South 
Africa, where many schools remain unconnected and disadvantaged after almost three decades of democracy (Malinga 2020).

\subsection{Working from Home during COVID-19 National Lockdown}

Feminist scholars have preoccupied themselves with discussions about the gendered nature of work. These scholars have engaged in strenuous debates over women's perennial association with the private domain of the home. The COVID-19 pandemic reignited this discussion when work from home arrangements became the new norm.

Malani, a South African woman of Indian descent, assessed her position as a school principal and how it infringes on the time she spends at home with her family and on her relaxation time. During the lockdown, she said that she could sleep in late and spend more time with her family indoors. Theolene, the principal of Hope Primary school, who hails from a traditional white-Afrikaner household, stated that the national lockdown afforded her more family time and the opportunity to perform her motherly duties. She was able to juggle her personal studies and schoolwork in the mornings and reserve the afternoons for her family - cooking their meals, driving around the farm looking at the animals and spending time with her husband and son. She considered this a good balance instead of being at school until 17:00 or 23:00 if there was a SGB meeting.

Gina comes from a Christian background. She stated that her status as a wife is rooted in biblical principles that posit that the husband is the head of the home. They, however, work as equal partners. Thus, in terms of relationship prioritisation, after God, her family takes priority over everything else. She lives with her husband and her mother. Both these family members have been very supportive of her throughout the COVID19 national lockdown. She mentioned that her husband would bring her coffee while she was busy with work, and they would go for a drive or a walk in the garden. Gina attributes her successful work and family life balance to the partnership she has established with her husband.

Both Telma's children are young adults and no longer live with her and her husband. During the national lockdown, she was home alone most of the time because her husband is an advanced life support paramedic and only returns home on weekends. Telma narrates her experiences of working 
from home as follows:

I made sure that I had a special routine. I would do some work and then I would put in an hour for reading in the afternoon. My husband was not with me all the time because he is an essential worker - but I'm okay with it because I'm so used to being on my own for long periods of time. Thus, it didn't really get to [upset] me.

From this excerpt, it appears that Telma's motherly and wifely role is minimal. She is thus better able to achieve a work and personal life balance. She mentions that both she and her husband grew up in white middle-class households, where both parents worked full-time jobs. As a result of her upbringing, being a working mother and wife has never been an issue in her household.

Each principal in this study hailed from a different cultural and social background. It was, therefore, evident that the level of cultural and gender role expectations of women varied from one context to another. The data analysis also revealed that despite the enactment of different gender role expectations within their households, as women in school leadership positions, the participants enjoyed support from their husbands. Tshweneyagae (2019: 10) observes that 'today, more men, especially in urban areas, are more involved in helping their working women with home chores, which is not likely to be the case with rural areas'.

For the most part, most of the participants reflected positively on the flexi-work from home arrangements. They enjoyed the autonomy of planning their work schedules in relation to what needed to be prioritised and reached higher levels of harmony in their work-life balance. The participants reported enjoying the love, support, co-operation and encouragement of spouses and other family members and noted general work-family enrichment. Some participants commented that the decreased social interaction left them feeling isolated and disconnected from their staff and students. While their home environments were portrayed as stable and conducive to effective work, some of their staff and students did not have the necessary infra-structure and resources to render their work from home productive. The experiences of the participants in this study are not representative of the broader South African context. The country has seen an exponential increase in gender-based violence, child rapes and killings (www.dailymaverick.co.za); 
food insecurity (www.statssa.gov.za); and housing insecurity (Parke \& Adebayo 2021) during lockdown. Thus, the link between flexi-work, work from home, work-life balance, and productivity remains a contested matter in the South African context.

\subsection{Capitalising on Emotional and Affective Labour: An Ethic of Care and Compassion}

All four principals also asserted that leading their schools through the COVID-19 crisis required them to become more caring, compassionate, and considerate of their staff's, learners', and their parents'/ guardians' wellbeing. Traditionally, women's stereotypical view as compassionate and nurturing beings has been perceived as a weakness in leadership and management discourse. Such qualities have been construed as being inconsistent with effective leadership. However, during COVID-19 compassionate and care-focused leadership has proven to be a strength rather than a weakness. Crisis times, such as the COVID-19 pandemic, are periods characterised by great uncertainty and anxiety amongst learners, their parents and teachers; therefore, school leaders need to exercise a pedagogy of care (Noddings 2010). Leading by example through displaying compassion and empathy proved to be an effective way for these four principals to lead their schools through the anxiety and uncertainty caused by the pandemic. Eliadis (2019) posits that during a crisis, followers' interests move in the direction of essential needs, and such concerns are regularly weighed down with emotion.

At Hope Primary and Tranquil Primary schools, principals often sent staff and learners messages of encouragement and hope on social media platforms such as their Facebook page and the schools' WhatsApp groups. Gina mentioned that she shows care and nurturance by giving hugs (physical contact), but she found it difficult to adjust to the lockdown and the social distancing structures. Remaining positive through the crisis and trying to establish how she would support her staff and learners without being physically present made her contact each of her staff members individually and encourage them by praying with them. Her actions support Eagly's (2007) assertion that generally women tend to be more religiously inclined and empathetic towards their followers. 


\section{Conclusion}

In reviewing the data for this study, what emerged is that the four principals' experiences were influenced by their different school contexts, demographics and personal biographic backgrounds. Despite them experiencing anxiety and uncertainty due to the COVID-19 pandemic, they were able to persevere and continue leading their schools through uncertainty in unprecedented times. They showed resilience, adaptability, and courage - vital leadership attributes for leading in a time of crisis. The strategic plans to implement remote teaching and learning during the national lockdown highlighted the deep fissures between the 'haves' and the 'have nots'. Many working-class parents lost their jobs or suffered salary reductions, with knock-on effects which gravely impacted the schools' finances and resource availability. These financial shockwaves were more evident in public government schools than in independent schools, which navigated and transitioned to online teaching and learning more organically than public counterparts because they had access to financial and technological resources.

The participants showed a preference for contingency crisis leadership. They did not shy away from being assertive or authoritative when the need arose.

All four principals' narratives cohered around the importance of working collaboratively and privileging teamwork during an unprecedented crisis such as COVID-19. Although they were unable to enjoy the benefits of intercorporeality (i.e., affective encounters with others/otherness made in and through the body) during the crisis, the participants displayed higher levels of empathy towards their staff, learners, and parents. The lockdown, by and large, had a positive effect on staff and stakeholder relationships. However, the remnants of South Africa's apartheid legacy did highlight intersectional biases within and outside their schools. At least one of the participants had to contend with microaggressions, which resulted in her enacting authoritative leadership. Cumulatively, the data revealed that relational leadership and an enactment of care and compassion served as the participants' greatest leadership strengths.

The study also revealed that female principals generally experience challenges in balancing their work and family lives. Often demanding work hours and the additional weight of cultural gender expectations factor into 
their emotional, affective and physical energies. The participants in this study revealed that the national lockdown enabled them to achieve better work and family integration because they could work from home. The personal home and family circumstances of all four participants emerged as unrepresentative of broader South African society. All participants reported conducive home environments and supportive family relations that rendered their leadership experiences manageable.

COVID-19 has reminded us that plagues, pestilences and pandemics are not new phenomena. History reports that these are phenomena that human beings have had to navigate in times past. Educational institutions and education leaders have had to reinvent and reimagine the education enterprise to respond to these crises. COVID-19 and the lockdowns have reaffirmed that school closures are as controversial and disruptive today as they were in the past and that they are not the ideal nor the preferred form of teaching and learning for learners, teachers and other significant education partners. However, 21st century technological affordances have facilitated virtual teaching and learning. It has also exposed - more starkly - the vast inequities that plague socio-economically underserved/serviced societies.

Dedication: This article is dedicated to Anver Williams (27 December 1964 - 20 September 2020.)

\section{References}

Alaimo, S. 2018. Trans-corporeality. In Braidotti, R. \& M. Hlavajova (eds.): Posthuman Glossary. London: Bloomsbury.

Allen, T.D., E.L Herst, C.S. Bruck \& M. Sutton 2000. Consequences Associated with Work-to-family Conflict: A Review and Agenda for Future Research. Journal of Occupational Health Psychology 5, 2: 278 - 308. Available at: https://doi.org/10.1037/1076- 8998.5.2.278

Archibald, M., R. Ambagtsheer, M. Caser \& M. Lawless 2019. Using Zoom

Videoconferencing for Qualitative Data Collection: Perceptions and Experiences of Researchers and Participants. International Journal of Qualitative Methods 18,1:1-8.

https://doi.org/10.1177/1609406919874596

Atterberry, T. 2020. Education during Plagues and Pandemics: A Historical Perspective. Available at: 
https://blog.gale.com/education-during-plagues-and-pandemics-ahistorical-perspective/

Ball, S. 2003. The Teacher's Soul and the Terrors of Performativity. Journal of Educational Policy 18,2: 215 - 228.

https://doi.org/10.1080/0268093022000043065

Bartling, E. 2013. Female High School Principals in Rural Midwestern School Districts: Their Lived Experiences in Leadership. PhD awarded at, University of Wisconsin Milwaukee, Wisconsin. Available at: https://dc.uwm.edu/etd/75/.

Bedeian, A.G., B.G. Burke \& R.G. Moffett 1988. Outcomes of Work Family Conflict among Married Male and Female Professionals. Journal of Management 14,3: 475 - 491. Available at:

https://doi.org/10.1177/014920638801400310

Blackmore, J. 2013. A Feminist Critical Perspective on Educational Leadership. International Journal of Leadership in Education 16, 2: 139 - 154. https://doi.org/10.1080/13603124.2012.754057

Blackmore, J. 1996. Doing 'Emotional Labour' in the Education Market Place: Stories from the Field of Women in Management. Discourse: Studies in the Cultural Politics of Education 17, 3: 337 - 349. https://doi.org/10.1080/0159630960170304

Black, S., C.A. Spreen \& S. Vally 2020. Education, COVID-19 and Care: Social Inequality and Social Relations of Value in South Africa and the United States. South African Review of Education 26, 1: 40 - 61.

Boin, A., S. Kuipers \& W. Overdijk 2013. Leadership in Times of Crisis: A Framework for Assessment. International Review of Public Administration 18,1: 79 - 91.

https://doi.org/10.1080/12294659.2013.10805241

Bond, L.A., M.F. Belenky \& J.S. Weinstock 2000. The Listening Partners Program: An Initiative Toward Feminist Community Psychology in Action. American Journal of Community Psychology 28, 5: 697 - 730. https://doi.org/10.1023/A:1005149821279 PMid:11043111

Bullard, R.D. 2001. Environmental Justice in the $21^{\text {st }}$ Century: Race still Matters. Phylon 49, 3/4: 165. https://doi.org/10.2307/3132626

Bush, T. \& D. Glover 2016. School Leadership and Management in South Africa: Findings from a Systematic Literature Review. International Journal of Educational Management 30, 2:1 - 26. https://doi.org/10.1108/IJEM-07-2014-0101 
Carlton, G. 2020. Higher Education and Pandemics: A History of Universities and Viral Outbreaks. Available at:

https://www.bestcolleges.com/blog/higher-education-and-pandemics/.

Cheng, Y. 2018. Examining School Leadership Effects on Student Achievement: Of Contextual Challenges and Constraints. Cambridge Journal of Education 48,1: 21 - 45.

https://doi.org/10.1080/0305764X.2016.1221885

Dahiya, A. 2020. The Phenomenology of Contagion. Journal of Bioethical Inquiry 7, 1: 519 - 523. Available at: https://doi.org/10.1007/s11673020-09997-4 PMid:32840826 PMCid:PMC7445722

de Klerk, M. \& W. de Klerk 2020. Crises Containment Management in South African Schools: A Critical Review. Journal of Psychology in Africa 20, 6: 599-604. https://doi.org/10.1080/14330237.2020.1842442

Department of Co-operative Governance and Traditional Affairs (South Africa) 2020. Disaster Management Act, 2002: Amendment of Regulations Issued in Terms of Section 27(2) (Act no 57 of 2002): Declaration of Natural Disaster. (Notice 312). Government Gazette, 430086, 15 May. Available at:

https://archive.opengazettes.org.za/archive/ZA/2020/governmentgazette-ZA-vol-657-no-43096-dated-2020-03-15.pdf

Department of Statistics South Africa 2020. Loss of Income Resulting from the COVID-19 Pandemic May Lead to Higher Levels of Food Insecurity in SA. Available at: http://www.statssa.gov.za

Diprose, R. 2002. Corporeal Generosity: On Giving with Nietzsche, Merleau-Ponty and Levinas. New York: SUNY.

Drake, J.J. 2018. It's a Dangerous World in There: Leadership Methods and Actions of School Administrators during Emergency Situations and Times of Crises. PhD, awarded at, Northern Illinois University, De Kalb, Illinois.

Dube, B. 2020. Rural Online Learning in the Context of COVID-19 in South Africa: Evoking of COVID-19 in South Africa. Multidisciplinary Journal of Educational Research 10,2:136 - 157.

https://doi.org/10.4471/remie.2020.5607

Eagly, A.H. 2007. Female Leadership Advantage and Disadvantage:

Resolving Contradictions. Psychology of Women Quarterly 1 - 12. https://doi.org/10.1111/j.1471-6402.2007.00326.x

Eliadis, A. 2019. Leading through Turbulent Times and Crises: What 
Attributes Play a Role in the Ability of Women Leaders to Navigate Crises in their Organization. Awarded at, Fielding Graduate University, Department of Philosophy. ProQuest.

Ellis, E. 18 June 2020. Gender-based Violence is South Africa's Second Pandemic says Ramaphosa. Daily Maverick. Available at:

https://www.dailymaverick.co.za/article/2020-06-18-gender-basedviolence-is-south-africas-second-pandemic-says-ramaphosa/

Gainey, B. 2010. Crises Management in Public Districts. Organization Development 28,1: 89 - 95. Available at: https://digitalcommons.kennesaw.edu/facpubs/

Gatwiri, K. 2021. Battlegrounds: Highly Skilled Black African Professionals on Racial Microaggressions at Work. Available at:

https://theconversation.com/battlegrounds-highly-skilled-blackafrican-professionals-on-racial-microaggressions-at-work-149169

Hargreaves, A. 2005. The Emotions of Teaching and Educational Change. In Hargreaves, A. (eds.): Extending Educational Change: International Handbook of Educational Change. Netherlands: Springer.

https://doi.org/10.1007/1-4020-4453-4

Hesse-Biber, S. 2010. Qualitative Approaches to Mixed Methods Research.

Qualitative Inquiry 16, 6: 455 - 468. https://doi.org/10.1177/1077800410364611

Hill, J.E., J.G. Grzywacz, S. Allen, V.L. Blanchard, C. Matz-Costa, S. Shulkin \& M. Pitt-Catsouphes 2008. Defining and Conceptualizing Workplace Flexibility. Community, Work \& Family 11, 2:149 - 163. Available at: https://doi.org/10.1080/13668800802024678

Hochschild, A.R. 1983. The Managed Heart: Commercialization of Human Feelings. Berkeley: University of California Press.

Hougaard, R. \& J. Carter 2018. The Mind of the Leader. Boston, MA: Harvard Business School Publishing Corporation. Available at: https://doi.org/10.1177/160940690400300104.

Jackson. L.T.B. \& E.I. Fransman 2018. Flexi Work, Financial Well-being, Work - Life Balance and their Effects on Subjective Experiences of Productivity and Job Satisfaction of Females in an Institution of Higher Learning. South African Journal of Economic and Management Sciences 21,1. Available at: https://doi.org/10.4102/sajems.v21i1.1487 Jaegar, M.M. \& E.H. Blaabaek 2020. Inequality in Learning Opportunities during COVID-19: Evidence from Library Takeout. ELSEVIER 68:1-5. 
Available at: https://doi.org/10.1016/j.rssm.2020.100524.

Jansen, J. 2020. Data or Bread? A Policy Analysis of Student Experiences of

Learning under Lockdown. South African Review of Education 26, 1: $167-181$.

Kainuwa, A. \& N.B.M. Yusuf 2013. Influence of Socio-economic and Educational Background of Parents on their Children's Education in Nigeria. International Journal of Scientific and Research Publications 3,10: $1-8$.

Kezar, A.J. \& E.M. Holcombe 2017. Shared Leadership in Higher Education: Important Lessons for Research and Practice. Washington, DC: American Council on Education.

https://doi.org/10.1007/978-94-017-9553-1_537-1

Klann, G. 2003. Crisis Leadership: Using Military Lessons, Organizational Experiences, and the Power of Influence to Lessen the Impact of Chaos on the People You Lead. (Scisco, P. ed.). North Carolina, United States of America: CCL Press.

Kostogriz, A. 2012. Accountability and the Affective Labour of Teachers: A Marxist - Vygotskian Perspective. The Australian Educational Researcher 39,4: 397 - 412.

https://doi.org/10.1007/s13384-012-0072-x

Lee, M. \& P. Hallinger 2012. National Contexts Influencing Principals' Time Use and Allocation: Economic Development, Societal Culture, and Educational System. School Effectiveness and School Improvement 23, 4: $461-482$.

https://doi.org/10.1080/09243453.2012.678862

Mahaye, N.E. 2020. The Impact of COVID-19 Pandemic on South African Education: Navigating Forward the Pedagogy of Blended Learning. KwaZulu-Natal Department of Education.

Malinga, S. 2020. COVID-19 Exposes SA's Digital Fractures, Inequality. Available at: $\underline{w w w . i t e w e b . c o . z a}$

Mayer, C., R. Oosthuizen \& S. Surtee 2017. Emotional Intelligence in South African Women Leaders in Higher Education. SA Journal of Industrial Psychology 43, 0:1-12. Available at:

https://doi.org/10.4102/sajip.v43i0.1405

McCarthy, S.P. 2012. K-12 School Leaders and School Crisis: An Exploration of Principals' School Crisis Competencies and Preparedness. Unpublished doctoral dissertation, awarded at University of Pittsburgh, 
Pittsburgh, Pennsylvania. Available at:

https://core.ac.uk/download/pdf/12211014.pdf.

Merriam, S. \& E. Tidsell 2016. Qualitative Research: A Guide to Design Implementation. San Francisco, California: Jossey-Bass.

Miller, E 2020. The COVID-19 Pandemic Crisis: The Loss and Trauma Event of Our Time. Journal of Loss and Trauma 1-13. Available at: https://doi.org/10.1080/15325024.2020.1759217

Moore, M.S. 2018. Leadership under Fire: A Phenomenological Study of Senior Administration's Perceived Leadership Identity and Crisis Response at Higher Education Institutions in the United States. Unpublished doctoral dissertation, awarded at, St John Fisher College, New York. Available at: www.fisherpub.sjfc.edu/education_etd.

Morse, S.S. 2007. Pandemic Influenza: Studying the Lessons of History. Proceedings of the National Academy of Sciences 104, 18: 73 - 134. https://doi.org/10.1073/pnas.0702659104

Moyo, Z. \& J.C. Perumal 2019. Disadvantaged School Contexts and Female School Leadership in Zimbabwe. International Journal of African Renaissance Studies - Multi-, Inter-and Transdisciplinary 14, 1: 105-183. https://doi.org/10.1080/18186874.2019.1610900

Naidoo, B. \& J.C. Perumal 2014. Female Principals Leading at Disadvantaged Schools in Johannesburg, South Africa. Educational Management Administration \& Leadership 42, 6: 808 - 824. Available at: https://doi.org/10.1177/1741143214543202.

Netolicky, D. 2020. School Leadership during a Pandemic: Navigating Tensions. Murdoch University, Department of Education. Perth, Australia: Emerald Publishing Limited.

https://doi.org/10.1108/JPCC05.2020.0017

News24, 04 August 2020. Available at:

https://www.news24.com/news24/southafrica/news/lockdown-anxietyfills-gauteng-schools-but-principals-determined-to-sail-throughuncharted-waters-20200804

Noddings, N. 2010. Moral Education in an Age of Globalization. Educational Philosophy and Theory 42, 4: 390 - 396. Available at: https://doi.org/10.1111/j.1469-5812.2008.00487.x

Nyenswah, S., C. Engineer \& D. Peters 2016. Leadership in Times of Crisis: The Example of Ebola Virus Disease in Liberia. Health Systems \& Reform 2,3: 194-207. 


\section{https://doi.org/10.1080/23288604.2016.1222793}

Obura, A. 2003. Never Again: Educational Reconstruction in Rwanda. International Institute of Educational Planning. Available at:

https://unesdoc.unesco.org/ark:/48223/pf0000133051

Owusu-Fordjour, C., C.K. Koomson \& D. Hanson 2020. The Impact of COVID-19 on Learning - The Perspective of the Ghanaian Student. European Journal of Education Studies 7, 3: 88 - 101.

https://doi.org/10.5281/zenodo.3753586

Oyeniran, R. \& I. Anchomese 2018. Women's Leadership Experiences: A

Study of Ivorian Women Primary School Principals. Journal of Educational Issues 4,1: 148 - 173.

https://doi.org10.5296/jei.v4i1.13042

Parke, D. \& P. Adebayo 2021. Health, Housing, and Urban Inclusion in the Time of COVID-19: Evidence from Detroit and Durban. Journal of Inclusive Cities and Built Environment 1, 1:1 - 15.

Perumal, J.C. 2014. Enacting Critical Pedagogy in an Emerging Democracy:

Narratives of Pleasure and Pain. Education and Urban Society 48, 8:

743 - 766. https://doi.org/10.1177/0013124514541466

Perumal. J.C 2015. Critical Pedagogies of Place: Educators' Personal and Professional Experiences of Social (In)Justice. Teaching and Teacher Education 45:25 - 32. Available at:

http://dx.doi.org/10.1016/j.tate.2014.09.004

Powers, S. \& K. Azzi-Huck 2016. The Impact of Ebola on Education in

Sierra Leone. Available at:

https://0-blogs-worldbank-org.ujlink.uj.ac.za/education/impact-ebolaeducation-sierra-leone

Pullen, A. \& C. Rhodes 2010. Revelation and Masquerade: Gender, Ethics and the Face. In Simpson R. \& P. Lewis (eds.): Concealing and Revealing Gender. Palgrave: Basingstoke.

Pullen, A. \& S.J. Vachhani 2020. Feminist Ethics and Women Leaders: From Difference to Intercorporeality. Journal of Business Ethics 1 - 12.

Available at: https://doi.org/10.1007/s10551-020-04526-0

PMid:32398886 PMCid:PMC7214853

Raja, S. \& S.L. Stein 2014. Work - Life Balance: History, Costs, and Budgeting for Balance. Clinics in Colon and Rectal Surgery 27, 2:7174. https://doi.org/10.1055/s-0034-1376172

PMid:25067921 PMCid:PMC4079063 
Salata, C., A. Calistri, C. Parolin \& G. Palù 2020. Coronavirus: A Paradigm of New Emerging Zoonotic Diseases. Pathogens and Disease 77, 9:15. https://doi.org/10.1093/femspd/ftaa006

Segoei, B.A. \& T. Bisschoff 2019. Parental Involvement as Part of Curriculum Reform in South African Schools: Does it contribute to Quality Education? Africa Education Review 16, 6: 165 - 182. https://doi.org/10.1080/18146627.2018.1464692

Shapiro, M., C. Ingols \& S. Blake-Beard 2008. Confronting Career Double Binds: Implications for Women, Organizations, and Career Practitioners. Journal of Career Development 34:309 - 333.

https://doi.org/10.1177/0894845307311250

Slaughter, A.M. 2012. Why Women Still can't Have it All. The Atlantic Monthly 85 - 102. Available at:

http://www.theatlantic.com/magazine/archive/2012/07/w hy-women-still-cant-have-it-all/309020/

Smith, S. \& D. Riley 2012. School Leadership in Times of Crisis. School Leadership and Management 32,1: 67 - 71. Available at: https://doi.org/10.1080/13632434.2011.614941.

South African Department of Health 2020. Update of COVID-19. Available at: https://sacoronavirus.co.za/2020/03/31/update-of-covid-19-31stmarch-2020/

Stern, A.M., M.S. Cetron \& H. Markel 2009. Closing the Schools: Lessons from the 1918-19 U.S. Influenza Pandemic. Health Affairs 28,1.

Supplement. Available at: https://doi.org/10.1377/hlthaff.28.6.w1066. Sukal, F.M. 2009. Alternative Work Arrangements and their Relationship to Work and Nonwork Outcomes: A Research Synthesis. Unpublished doctoral thesis, awarded at, Alliant International University, Los Angeles, CA. Available at:

http://www.scielo.org.za/scielo.php?script=sci_nlinks\&ref=4413297\& pid=S2222-3436201800010000300096\&lng=en.

Tajlili, M.H. 2014. A Framework for Promoting Women's Career Intentionality and Work - Life Integration. The Career Development Quarterly 62: 254-267. https://doi.org/10.1002/j.2161-0045.2014.00083.x

Tshweneyagae, D. 2019. Balancing the Roles: Societal/ Cultural Gender Expectations and Roles Conflict among African Working Women. IOSR Journal of Humanities and Social Science 24, 6: 6 - 11. https://doi.org/10.9790/0837-2406020611 
UNESCO 2020. COVID-19 Educational Disruption and Response. Geneva: UNESCO. Available at: https://en.unesco.org/news/covid-19educational-disruption-and-response.

Whitney, S. 2018. Byproductive Labor: A Feminist Theory of Affective Labor beyond the Productive - Reproductive Distinction. Philosophy and Social Criticism 44, 6:637 - 660. https://doi.org/10.1177/0191453717741934

Wittenberg-Cox, A. 2020. What do Countries with the Best Coronavirus Responses have in Common? Women Leaders. Available at: https://www.forbes.com/sites/avivahwittenbergcox/2020/04/13/whatdo-countries-with-the-best-coronavirus-reponses-have-in-commonwomen-leaders/?sh=1561ff443dec

Woodcock, J. 2017. Working the Phones: Control and Resistance in Call Centres. London: Pluto. https://doi.org/10.2307/j.ctt1h64kww

Zembylas, M. 2005. Beyond Teacher Cognition and Teacher Beliefs: The Value of Ethnography of Emotions in Teaching. International Journal of Qualitative Studies in Education 18, 4: 465 - 487. https://doi.org/10.1080/09518390500137642

Zikhali, J. \& J.C. Perumal 2015. Leading in Disadvantaged Zimbabwean School Contexts: Female School Heads' Experiences of Emotional Labour. Education Management Administration Leadership 44, 3:1 16. https://doi.org/10.1177/1741143214558572

Felicia Williams

Postgraduate Candidate Department of Education Leadership \& Management University of Johannesburg Johannesburg wfelicia416@gmail.com

Professor Juliet Perumal Department of Education Leadership \& Management University of Johannesburg Johannesburg julietp@uj.ac.za 